\title{
4. GENDER EQUALITY AND CAREER GUIDANCE IN A NORDIC CONTEXT
}

\begin{abstract}
In this chapter we explore how the question of gender equality in the Nordic countries is connected with career guidance. The Nordic welfare states are generally considered to take on a higher degree of responsibility for reducing inequalities than other state forms. Despite gender equality being high on the agenda, we argue that the underlying strong ideology of individual free career choice creates a dilemma for career practitioners on how to approach the issue of gender guidance. We argue that career guidance should take an intersectional perspective and use the examples of Norway and Sweden to highlight the importance of policy goals being followed up with concrete measures.
\end{abstract}

\section{INTRODUCTION}

Gender equality has been an important political issue in the Nordic countries since the middle of the 20th century (Eydal et al., 2015). Throughout the Nordic region political decisions have been taken to ensure that families can balance and combine working life and domestic responsibilities (Öun, 2014). As a result of such legislation, the Nordic countries have the highest level of female participation in the labour market in the world and a well-developed self-image of being gender equal (Martinsson, Griffin, \& Nygren, 2016). From the 1960s onwards there have been a growing number of women in the labour market, both due to the feminist movement and the lack of labour, with women seen as a labour reserve (Hirdman, 2001). From an outside perspective, the Nordic countries are often identified as a utopia with respect to gender equality and are placed highly in various gender equality rankings (Castro-Garcia \& Pazos-Moran, 2016; Green, 2015; Lister, 2009; Hooley, Chapter 3, this volume; Martinsson et al., 2016).

Historically the focus of gender equality has been on women's careers and their ability to balance working life with the responsibilities of childcare and other domestic chores (e.g. Ellingsæter, 2016). The focus has now shifted to the gender division of labour and the engagement of men in domestic and care work (e.g. Brandth \& Kvande, 2016; Reisel \& Teigen, 2014). Other important questions are boy's underachievement in school and girls over representation in higher education 
(Lahelma, 2014; Zimmerman, 2018) and the consequences of these educational disparities throughout the life course (NOU, 2019:3).

Career guidance practitioners, particularly in schools, are often pointed at by interest groups and by governments as being important in solving the gender division of labour (e.g. Meld. St nr. 7, 2015-2016; SOU, 2015:50). The way career guidance personnel engage with this question varies between different professionals, schools and countries in the Nordic region (Mathiesen, Buland, \& Bungum, 2010; Skolinspektionen, 2013).

Our position and theoretical grounding is based on an understanding of gender as something socially constructed and constituted, something that is done rather than something that is (Connell, 2004; Lykke, 2009). We can not escape the underlying dualistic view on gender, but our ambition is to visualise and problematise this view. The gender dichotomy constructs the expectations on individuals based on assumptions of their biological gender (Connell, 2004). Since this is the way that the statistics are reported in the Nordic countries, we have to discuss both gender as biology and gender as social construct. Nordic gender equality policies are based on this dualistic view of gender, and on the norm of families with two parents, a mother and a father (Martinsson et al., 2016).

To discuss gender we also take into account that gender does not necessarily affect peoples' position in society by itself, categories such as social background, ethnicity, functionality, sexuality, identity, age and religion are also important for understanding power structures effect on peoples life (de los Reyes \& Mulinari, 2005; Røysum, 2016). We therefore take intersectionality as an analytical perspective, emphasise the relational aspect of gender rather than the individual and draw on the theoretical viewpoint that politics and legislation matters for what is seen as possible by individuals and for constructing and changing social norms in society (Bromseth \& Darj, 2010; Wikstrand, 2019).

\section{UNDERSTANDING THE "NORDIC GENDER EQUALITY MODEL”}

How a country deals with gender equality has a significant and direct impact on how the labour market is organised (e.g. Halrynjo \& Teigen, 2016). An understanding of gender equality (and inequality) is therefore of importance for the field of career guidance. All of the Nordic countries share a sense of fulfilment in these matters and possess a self-image of being pioneers in gender equality. Sweden passed its first law on gender equality in 1939 (NIKK, 2018). The Finns was the first country in the world to grant women full political rights in 1906 (Ministry of Social Affairs and Health, 2019). Iceland has been in the spotlight recently for implementing an equal pay standard (described as certified equality) (Wagner, 2018). The Norwegians take pride in being the first country worldwide to enforce the fathers' quota, which ensures that men take some paternity leave, in 1993 (Kitterød \& Halrynjo, 2019, and Denmark can boast that it has the highest day-care coverage for young children 
(Eydal \& Rostgaard, 2011). These are only some examples of Nordic policies that have contributed to the strong gender equal identity and self-image in our region.

Nevertheless, there are still challenges to deal with. The gender pay gap remains (Holst, 2016; Magnusson \& Nermo, 2014), women are more likely than men to work part time (Öun, 2014; Statistisk Sentralbyrå, 2018) and we are still facing a care deficit, meaning that much care work is either unpaid or poorly payed (Boye, 2014). The Nordic countries also have a clear gender division of labour (e.g. Reisel, 2014). Men dominate STEM (science, technology, engineering and mathematics) occupations and women are over-represented in HEED (Health care, Elementary Education, and Domestic) (Tellhed, Bäckström, \& Björklund, 2017). Tasks coded as STEM are viewed as masculine, while tasks coded as HEED are viewed as feminine (Wajcman, 1991). In recent years, we have seen a movement towards more women in formerly masculine coded areas such as medicine and law. Yet within these occupations there is still an internal gender division of labour, often referred to as the glass ceiling, where men tend to proceed in their careers into managerial positions more easily than women (SOU 2015:50; Teigen, 2014; Wikstrand, 2011). One question addressed has been about women's participation on company boards and top leadership position (Teigen, 2015). A 40-60\% balance between the sexes is the number identified by policymakers as 'gender mainstreaming' (Sjöstedt, Landén, \& Olofsdotter, 2016). Different occupations have different pay, influence and power in society and a gender balanced labour market is often recognised to provide the best use of talents, to lead to higher profits and provide a better work environment (Reisel \& Teigel, 2014; SOU 2015:50).

Nancy Fraser (1994) has argued that a modern welfare state should recognise the complexity of gender equality. It is situated between equality and equity, between treating women and men exactly the same and the assumption that one gender should be treated differently because they are different. Fraser (1994) argues that neither of these ways of looking at gender have a significantly impact, since they do not address exploitation in society. Furthermore, she argues for the need to rethink gender equality through the principles of antipoverty, antiexploitation, income equality; leisure-time equality; equality of respect, anti-marginalisation and anti-androcentrism. From these ways of looking at gender equality Fraser argues for a deconstruction and reconstruction of how we understand gender and how we code gender (Fraser, 1994).

While Fraser (1994) asked 'can we really look to the state to befriend women in male-dominated, racist, late-capitalist societies?", Hernes (1987) claims that the Nordic countries with their state forms are well equipped to reduce inequalities and transform themselves into gender equal societies. She describes three main aspects of gender equality that are used as arguments in policies and politics.

1. The right of the individual - connected to human rights and the ideal that men and women have equal rights to participate in society, without any concerns about consequences. 
2. Resources in society - focus on the added (often economic) value of having both men and women participating in society and the workforce.

3. Redistribution of power in society - men and women are assumed to have different experiences, values and interest. Equal participation is therefore necessary to ensure both groups interest.

Hernes argues that the second aspect, resources and economics, also referred to as the economic equity dimension (Teigen \& Skjeie, 2017), represents a more fragile base for gender equality (Hernes, 1987). Historically this has been a strong argument for women's participation in the labour market (Hirdman, 1999) and can be seen in a recent report from the OECD (2018), that highlights how the Nordic approach to gender equality has resulted in growth in GDP per capita of between $10 \%$ and $20 \%$. Hernes first and third point are related to what Teigen and Skjeie (2017) portray as the democratic parity dimension - a focus on factors like gender balance in political decision making, equal of opportunity structures within civil society, and equal rights to vote and hold office.

\section{GENDER EQUALITY POLICIES IN THE NORDIC COUNTRIES}

The issue of gender equality in the Nordic countries has long tradition starting in the 19 th century. Gender equality is not just a labour market issue or question of access to democratic representation but is also concerned with individual's relationships and family lives. The first parental leave insurance that gave fathers the right to leave when a baby was borne was introduced in all Nordic countries in 1970's and 1980 's. The idea that private life is important for gender equality was stressed by the women's movement in 1960's and 1970's. In some of the Nordic countries this is still something that is left out of policies as shown in Table 4.1.

If we examine the five Nordic countries official gender equality goals and identified prioritised areas, a slightly different take on gender equality and family policies becomes visible. We will here present these goals, obtained from the website Nordic Information on Gender (NIKK, 2018).

The table above shows the different gender equality goals in the Nordic countries for 2016-2019. The Danish focus is on rights and freedom of the individual and better utilisation of recourses and competences. This can be related to Hernes (1987) resource argument. This focus has meant that in Denmark the argument for earmarked paternity leave would affect the free choice of families and is therefore not possible (nikk.no, 2018). Data from the Gender Equality Index (GEI), ${ }^{1}$ reveals that Denmark, although well above EU average, has a relatively low scores for democratic parity compared the two other Nordic EU member countries (Finland and Sweden).

Sweden and Iceland are the two countries that address equal power based the principle of democratic parity and addressing Hernes' first and third point. Sweden is the only country that addresses the equal distribution of household and care work. The other countries equality goals are to be found some place in between these 
Table 4.1. Gender equality goals in the Nordic countries nikk.no (2018-05-22)

\begin{tabular}{|c|c|}
\hline Country & Gender equality goals \\
\hline Denmark & $\begin{array}{l}\text { - Rights and freedom for the individual } \\
\text { - Better utilisation of resources and talents } \\
\text { - Global gender equality measures }\end{array}$ \\
\hline Finland & $\begin{array}{l}\text { - Promotion of gender equality in the labour market and the workplace } \\
\text { - Supporting people's ability to combine paid work with family life and } \\
\text { - Parenthood } \\
\text { - Promotion of gender equality in education and sport } \\
\text { - Improvement of men's wellbeing and health } \\
\text { - Promotion of gender equality through political decision-making. }\end{array}$ \\
\hline Iceland & $\begin{array}{l}\text { - Equality in political administration } \\
\text { - Gender and power - representation in politics } \\
\text { - Equality in the labour market including addressing the gender pay gap } \\
\text { - Addressing gender-based violence } \\
\text { - Equality in the education system } \\
\text { - Addressing issues of gender equality for men }\end{array}$ \\
\hline Norway & $\begin{array}{l}\text { The gender equality policies aims to ensure equal opportunities and } \\
\text { the freedom to make choices, regardless of gender, ethnicity, religion, } \\
\text { functional ability and sexual orientation, among all people. Gender equality } \\
\text { is emphasised in areas such as: } \\
\text { - Childcaring and education } \\
\text { - Employment } \\
\text { - Protection against violence and violations } \\
\text { - The business world } \\
\text { - Health } \\
\text { - International contribution to gender equality }\end{array}$ \\
\hline Sweden & $\begin{array}{l}\text { The overarching goal is to enable women and men to have equal power to } \\
\text { shape society and their own lives. To achieve this goal, women and men } \\
\text { must have the same rights, opportunities and responsibilities in all areas of } \\
\text { life. } \\
\text { - Equal distribution of power and influence } \\
\text { - Economic gender equality } \\
\text { - Gender equality in health and healthcare } \\
\text { - Gender equality within education } \\
\text { - Equal distribution of unpaid household and care work } \\
\text { - Men's violence against women must stop }\end{array}$ \\
\hline
\end{tabular}

two ways of addressing the question of gender equality. The countries equality goals have consequences for how gender is addressed in relation to, for example, career guidance in the government's policy texts on career guidance in schools and throughout the life course. 
As the main focus in the Nordic countries has been on women's entry into STEM and the professionalisation of female coded occupations, some women's advances have been at the expense of others (Dahl, 2004). Using Frasers (1994) principles of gender equalities, Dahl argues that a focus on the professionalisation of home-helpers in terms of pay has occurred at the same time as the state uses neoliberal discourses and management principles to reduce their work to simple and measurable tasks. The implications may be that the positive changes in pay are merely superficial and there will not be a recognition of their work.

In various initiatives from the governments and other stakeholders in Sweden and Norway, career practitioners are pointed at as the group to fix the problem (Meld. St nr. 7 2015-2016:13; SOU, 2015:50; SOU, 2015:97). A key question has been how career guidance could be organised to effectively challenge assumptions about gender and work. An interesting point is that career guidance itself, as an occupational field, appears to have become massively gendered, with a considerably female dominance.

\section{GENDER EQUALITY AND CAREER GUIDANCE}

In this part we turn our focal point more specifically to career guidance and aim to describe how gender and gender equality is affecting career guidance in research, policy and guidelines for career practitioners. We will look closer into Norway and Sweden as examples of similar, but distinct approaches.

\section{In Research and Theory}

There has been a lot of research and theory development which addresses gender across a range of disciplines e.g. gender studies, sociology, political science, psychology and pedagogics. Such research shows how gender is an important factor in career decision-making. Boys and girls, men and women make career decisions that are gender stereotyped (e.g. Reisel \& Teigen, 2014). Therefore, it is interesting that the question of gender has been visible in career theory as a question about women's different and problematic careers (e.g. Blustein, 2015). Male careers are viewed as a norm, for example in the International Handbook of Career Guidance (Athanasou \& Van Esbroeck, 2008). Bimrose (2008) writes an interesting and important text on 'Guidance for girls and women'. The placement of the chapter, in the part that addresses problematic careers such as migration and disadvantaged social backgrounds, shows that women's careers are seen as different to the normal (male) career. It is notable that there is no chapter in this handbook on 'Guidance for boys and men'. From a Nordic perspective, where women have the world's highest labour market participation (Green, 2015), it makes little sense to talk about women's careers as problematic.

Career development theories will generally reflect the dominant target groups in the fixed point in time in which they are created (Bimrose, McMahon, \& Watson, 
2019). Historically, most of the influential career theorist have been men, leaving white, middle class males as the particular group of interest (Bluestein, 2015). Gottfredson is perhaps the most well-known exception from the last century. Her theory of circumscription and compromise recognises gender as a crucial influence on career development (Bimrose et al., 2019; Gottfredson, 2005). The growing prevalence of women in the workforce, lead eventually to an increase of career theory concerned with women's career development. But as some researchers have suggested, the somewhat limited scope seemed to continue with a focus on primarily young, urban and well-educated women (Bimrose et al., 2019). Comparing women's participation in the labour force together with care responsibilities between different countries, Bimrose, McMahon, and Watson (2015) conclude that geography matters and that we need an intersectional approach which examines the privileges and disadvantages of all women. Bimrose et al. (2019) suggest that some emerging career theories, might due to their more holistic, contextual and less rigid nature, be better suited to deal with issues of gender in the world of careers, eg. Bluestein's the psychology of working (Blustein, 2006), the systems theory framework of career development (Patton \& McMahon, 2014) and the chaos theory of career development (Pryor \& Bright, 2011).

\section{NORWAY AND SWEDEN - TWO DIFFERENT APPROACHES?}

Gender-equality in a country is influenced by how the concept of gender equality is perceived, understood and debated in public (Teigen \& Wangerud, 2009). Research has shown some differences in how gender equality is discussed and framed in the Nordic countries (Borchorst, Christensen, \& Siim, 2012; Dahlerup, 2002; Teigen \& Wangerud, 2009). In a comparative discourse analysis, Borchorst et al. (2002) identified a variation in the dominant main discourses in Scandinavia. In Norway a discourse on gender differences has been apparent, whereas in Sweden a discourse on women's subordination has been higher on the agenda, and in Denmark the focus has predominantly been on empowerment and freedom of choice. Dahlerup (2002) found, after analysing political discourses in Sweden and Denmark, that gender equality was significantly more politicised in Sweden with feminism as a clearly outspoken ideal among most political parties. Teigen and Wangerud (2009) conclude in their analysis that while the discourse on gender equality in Norway seems to be rooted in a strong belief in the steady linear process of harmonious development, Sweden takes on a more radical approach in the public debate where discussions around power systems, political insufficiencies and conflicts are more prominent.

An interesting question is how these different discourses together with the formal goals presented in Table 4.1 are reflected in career guidance policies and practice in each country. Using Norway and Sweden as two examples, two slightly different approaches emerge.

From a policy perspective in both Norway and Sweden the ambition on gender equality, especially regarding economic equity and available resources, is undoubtedly 
high. A variety of governmental white papers (Meld. St nr. 7 (2015-2016), Meld. St nr. 20 (2012-2013), NOU, 2011:18, 2012:15, 2019:3; SOU 2015:50, 2015:97) have been produced in the last decade to pinpoint and enhance measures to cope with the issue of gender segregation in the labour marked.

However, as a specific career guidance topic the picture is less clear. In both countries career guidance responsibility to address gender equality issues is written into school laws (Skolverket, 2013; Utdanningsdirektoratet, 2009). School counselling and career guidance are positioned to play an important role to help youth to making educational choices regardless of gender (Meld. St nr. 7, 2015-2016, p. 13; Skolverket, 2013). Beyond this there are differences between the countries.

We argue that the Norwegian belief that this will progress nicely on its own (Teigen \& Wangerud, 2009) contributes to the lack of a clear focus on gender in guidance strategy in Norway. Research reveals (Haugum, Mathiesen, Buland, \& Carlsson, 2016; Mathisen et al., 2010) that the Norwegian schools generally have not put much effort into making action plans to address gender equality issues. Mathisen et al. (2010) concludes that gender perspectives have a relatively peripheral place in the schools, amongst the counsellors, the teachers and the management. This study, followed by more recent studies on school counsellors (Buland et al., 2011; Buland, Mathiesen, \& Mordal, 2014; Haugum et al., 2016) confirms that gender perspectives are rarely acknowledged in guidance work with Norwegian youth. With the exceptions of a few enthusiasts, the majority of the counsellors report that they find it difficult to approach this topic. In many ways they lack the tools and meaningful approaches on how to do it (Schulstok \& Svoen, 2014).

In Sweden, a more radical approach (Teigen \& Wangerud, 2009), has pushed the development on one step further. The national agency for education (Skolverket) has produced a series of guidance for schools. In the advice for work with career guidance in schools the legislation on gender equality is made more explicit and responsibilities clarified. For example, the schools have a responsibility to provide career guidance for pupils and to make sure that children's vocational and educational choices are not affected by 'gender, social background or culture' (Skolverket, 2013).

Research conducted in 2013 in 32 schools found that gender stereotyped career choices were seen as a big problem, but that counsellors did not feel that they had tools to work with the issue (Skolinspektionen Rapport, 2013:5). This knowledge resulted in an initiative from the National Agency for Education in Sweden to promote a course in gender aware career guidance in 2013 which developed into a new approach to guidance (norm criticism) (Wikstrand \& Lindberg, 2015). Norm criticism was introduced to help students to understand power structures through examining norms in societies. There was also a shift from only talking about gender stereotypes to a more intersectional understanding of power structures, including social background, race, age, religion, functionality and sexuality and how these intervenes. Norm criticism aims to visualise taken for granted norms and show how breaking the norms excludes people and ways of living from education, work and 
other institutions (Wikstrand, 2019). Wikstrand and Lindberg (2015) wrote a book distributed to all headmasters in the country by the national agency for education in Sweden. Questions addressed in the book include the culture of masculinity (e.g. 'too cool for school') and the way in which gender and class stereotypes shape engagement with occupations.

\section{CAREER GUIDANCE IN BETWEEN GENDER EQUALITY GOALS AND FORMATION OF THE FREE WILL}

Our country has not yet engaged its daughters. Thousands of forces are not in use. (Collett, 1868)

Since those words were written, we have come a long way in the Nordic region. Gender equality is largely taken for granted, so are women's careers. It is men's careers, and what Lahelma (2014) refers to as the boys' discourse, that are presently in focus, as men underachieve in schools and are underrepresented in higher education. What we need to keep in mind, is that a narrow focus on gender only, might lead us to ignore socioeconomic background, migration and other categories important to understand peoples transitions throughout life. It is important to take an intersectional stand on gender to understand and work with people in transitions.

One challenge in Norway and Sweden is that most career counsellors meet the students for individual guidance first in the eighth or ninth grade. These interviews need to contain so much and it could be seen as encroachment to challenge individuals' view on gender (Bueland et al., 2014; Loven, 2000). As Haug (Chapter 14, this volume) discusses the ideology of career guidance in a Nordic context is focused on the individual with the individual viewed as capable of making free choices. Challenging individuals' gender norms and assumptions can be seen as challenging the idea of free will. The common understanding amongst the practitioners is that their clients must make their own independent choices and this may contribute to a general hesitation and refusal to bring forward gender perspectives, unless the clients themselves problematise the issue (Mathisen et al., 2010).

How the welfare system supports gender equality and the opportunity to combine family life with working life shapes how families in the Nordic countries organise their everyday life and their careers. For the field of career guidance it is therefore of importance to examine closer how career logic unfolds within the Nordic familyfriendly work model. Family-friendly policies have contributed to the high numbers of females in the Nordic workforce, and made careers more available to women. Yet we should also be aware of the challenges that come along. As Halrynjo (2017) argues, the rules of family-friendliness rest upon the notion of collective rights, protection, legal absence and reduced demands on achievement and performance. The rules of career, however, tend to favour the productive, dedicated, visible and non-stop worker who is competing in a strongly individualised competition. In 
receiving the well-intentioned and highly needed support, parents, mostly mothers, then face the constant risk of becoming 'the replaceable worker' and failing to meet the expectations of the career world (Halrynjo, 2017).

The different Nordic countries have different gender equality goals. Denmark stresses free choices for families while Sweden seeks to redistribute power in the private sphere as well as in public sphere. The point is that there is not one way to view or to work for gender equality in the Nordic countries. The disparities are partly due to what is viable in the different countries, partly on which political parties govern. Hernes three arguments for gender equality visualise that there is not one rationality that underpins gender equality in the Nordic region. If we compare Hernes (1987) aspects of gender equality only Sweden and now Iceland have gender equality goals that seek to reconstruct gender norms. These countries also apply to Frasers point about how we understand and code gender. The attention to the gender division of labour in the Nordic countries and the lack of competences within STEM and HEED relate to the idea of gender equality for economic reasons. This argument urges career guidance workers to try to get young people to aspire to occupations that challenges gender norms. But as the career guidance ideology in the Nordic countries is not to influence the clients, most career guidance workers find themselves in a dilemma when talking about the gender division of labour.

The idea that individuals have a free choice is strongly situated within career guidance. This paradox between the desire to validate and support individual choice and a recognition of structural inequality is buried in the ideology of career guidance in the Nordic states. The Swedish and Icelandic gender equality goals emphasise the redistribution of power and seek to reconstruct notions of masculinity and femininity. This approach shifts the focus from trying to get girls into STEM occupations and boys into HEED occupations towards trying to visualise and challenge the gender division of labour through pedagogics and norm critique (Kumashiro, 2009; Wikstrand, 2019).

Guidance approaches based on constructivism and social constructionism have traditionally been recognised as suitable for dealing with gender equality issues, due to their narrative focus and its ability to bring contextual and cultural elements to the table (Bimrose et al., 2019). We need, however, to be aware of the potential danger of the emphasis on personal agency in these approaches and the risk that career practitioners lose sight of structural and systemic barriers to career (Bimrose et al., 2019). The development of norm critique as a guidance approach offers one way to address these issues that is worth exploring further across the Nordic region.

\section{NOTE}

1 GEI is monitored by the European Institute for Gender Equality (EIGE). The aim is to map country variation within the EU regarding gender equality outcomes on a variety of variables such as work, money, knowledge, time, power, health, violence against women and intersecting inequalities (Teigen \& Skjeie, 2017). 


\section{REFERENCES}

Athanasou, J. A., \& Van Esbroeck, R. (Eds.). (2008). International handbook of career guidance. Dordrecht: Springer Science + Business B.V.

Bimrose, J. (2008). Guidance for girls and women. In J. A. Athanasou \& R. Van Esbroech (Eds.), International handbook of career guidance (pp. 375-404). Dordrecht: Springer Science + Business.

Bimrose, J., McMahon, M., \& Watson, M. (Eds.). (2015). Women's career development throughout the lifespan: An international exploration. London: Routledge.

Bimrose, J., McMahon, M., \& Watson, M. (2019). Women and social justice. Does career guidance have a role? In T. Hooley, R. Sultana, \& R. Thomsen (Eds.), Career guidance for emancipation-Reclaiming justice for the multitude (pp. 17-32). New York, NY: Taylor \& Francis/Routledge.

Bluestein, D. L. (2006). The psychology of working. Mahwah, NJ: Lawrence Erlbaum Associates, Inc.

Blustein, D. L. (2015). Implications for career theory. In J. Bimrose, M. McMahon, \& M. Watson (Eds.), Women's career development throughout the lifespan: An international exploration (pp. 219-230). London: Routledge.

Borchorst, A., Christensen, A. D., \& Siim, B. (2002). Diskurser om køn, magt og politik i Skandinavien [Discourses on gender, power and politics in Scandinavia]. In A. Borchorst (Ed.), Kønsmagt under forandring [Gender power in change] (pp. 247-266). Copenhagen: Hans Reitzels Forlag.

Boye, K. (2014). Hushållsarbetets tid och fördelning [The time and division of house hold work]. In K. Boye \& M. Nermo (Eds.), Lönsamt arbete - familjeansvarets fördelning och konsekvenser [Profitable work - The distribution and consequences of family responsibilities] (pp. 95-129). SOU 2014:28. Stockholm: Elanders Sverige AB.

Brandth, B., \& Kvande, E. (2016). Fedrekvoten som en del av likestillingspolitikken. Er jobben gjort? [The fathers quota as part of gender equality policies. Is the job done?]. In S. Halrynjo \& M. Teigen (Eds.), Ulik likestilling $i$ arbeidslivet [Different gender equality in workinglife] (pp. 80-98). Oslo: Gyldendal Akademisk.

Bromseth, J., \& Darj, F. (Eds.). (2010). Normkritisk pedagogik. Makt, lärande och strategier för förändring [Norm critical pedagogics]. Uppsala: Centrum för genusvetenskap.

Buland, T., Mathiesen, I. H., \& Mordal, S. (2014). AE skjønne itj, a våkne opp kvar dag å vil bli nå nytt ce. Skolens rådgivning i Møre og Romsdal, Sør-Trøndelag og Nord-Trøndelag [Evaluation of school-based guidance provision in Møre og Romsdal, Sør-Trøndelag og Nord-Trøndelag County]. Trondheim: NTNU, Program for livslang læring.

Castro-Garcia, C., \& Pazos-Moran, M. (2016). Parental leave policies and gender equality in Europe. Feminist Economics, 22(3), 51-73.

Collett, C. (1868). Sidste blade. Erindringer og bekjendelser, 1ste rakke-artikler [Essays on memories and reflections]. Kjøbenhavn: Gyldendal.

Connell, R. W. (2004). Gender. Cambridge: Polity Press.

Dahl, H. M. (2004). A view from the inside. Recognition and redistribution in the Nordic welfare state from a gender perspective. Acta Sociologica, 47(4), 325-337. doi:10.1177/0001699304048666

Dahlerup, D. (2002). Er ligestillingen opnaaet? Ligestillingsdebattens forskellighed i Danmark og Sverige [Has equality been achieved? Differences in gender equality discourses in Denmark and Sweden]. In A. Borchorst (Ed.), Kønsmagt under forandring [Gender power in change] (pp. 226-246). København: Hans Reitzels Forlag.

de los Reyes, P., \& Mulinari, D. (2005). Intersektionalitet. Malmö: Liber.

Ellingsæter, A. L. (2016). Mødre og jobb - I evig ubalanse [Mothers and work - In eternal imbalance?] In S. Halrynjo \& M. Teigen (Eds.), Ulik likestilling $i$ arbeidslivet [Different gender equality in workinglife] (pp. 37-53). Oslo: Gyldendal Akademisk.

Eydal, G. B., Gislason, I., Rostgaard, T., Brandth, B., Duvander, A.-Z., \& Lammi-Taskula, J. (2015). Trends in parental leave in the Nordic countries: Has the forward march of gender equality halted? Community, Work \& Family, 18(2), 167-181.

Eydal, G. B., \& Rostgaard, T. (2011). Gender equality revisited-Changes in Nordic childcare policies in the 2000s. Social Policy and Administration, 45, 161-179. 
Fraser, N. (1994). After the family wage. Gender equality and the welfare state. Political Theory, 22(4), 591-618.

Gottfredson, L. S. (2005). Applying Gottfredson's theory of circumscription and compromise in career guidance and counselling. In S. D. Brown \& R. W. Lent (Eds.), Career development and counseling (pp. 71-100). Hoboken, NJ: John Wiley \& Sons.

Green, A. (2015). Geographical perspectives on women's careers. Why and how space matters. In J. Bimrose, M. McMahon, \& M. Watson (Eds.), Women's career development throughout the lifespan: An international exploration (pp. 11-25). London: Routledge.

Halrynjo, S. (2017). Exploring the career logic within the Nordic work-family model. In B. Brandth, S. Halrynjo, \& E. Kvande (Eds.), Work-family dynamics: Competing logics of regulation, economy and morals (pp.189-208). London: Routledge.

Halrynjo, S., \& Teigen, M. (2016). Ulik likestilling i arbeidslivet [Different gender equality in workinglife]. In S. Halrynjo \& M. Teigen (Eds.), Ulik likestilling $i$ arbeidslivet (pp. 13-36). Oslo: Gyldendal Akademisk.

Haugum, M. H., Mathiesen, I. H., Buland, T. H., \& Carlsson, E. (2016). Mangfold for innovasjon -Om etnisitet og kjønn $i$ videregående opplcering og næeringsutvikling $i$ Nord-Trøndelag. [Diversity for innovation - Ethnicity and gender in upper secondary education and business development in NordTrøndelag]. TFoU-rapport 2016:15. Steinkjer: Trøndelag Forskning og Utvikling AS.

Hernes, H. (1987). Welfare state and women power: Essays in state feminism. Oslo: Norwegian University Press.

Hirdman, Y. (1999). Kvinnorna i välfärdstaten. Sverige 1930-1990 [The women in the well fare state]. In C. Florin \& Y. Hirdman (Eds.), Kvinnohistoria [Women history] (pp. 203-218). Stockholm: Utbildningsradion.

Hirdman, Y. (2001). Med kluven tunga. LO och genusordningen [With chapped tongue]. Stockholm: Atlas.

Holst, C. (2016). Frie forhandlinger og "likelønnas elendighet" [Free negotiations and the sorrow of equal pay]. In S. Halrynjo \& M. Teigen (Eds.), Ulik likestilling $i$ arbeidslivet [Different gender equality in workinglife] (pp. 54-79). Oslo: Gyldendal Akademisk.

Kitterød, R. H., \& Halrynjo, S. (2019). Mer likestilling med fedrekvote? Naturlige eksperimenter i norsk kontekst [More gender-equality with a father quota? Quasi-experimental studies in the Norwegian context]. Tidsskrift for kjønnsforskning, 43(2), 71-89.

Kumashiro, K. K. (2009). Against common sense. Teaching and learning toward social justice. London: Routledge.

Lahelma, E. (2014). Troubling discourses on gender and education. Educational Research, 56(2), 171-183. doi:10.1080/00131881.2014.898913

Lister, R. (2009). A Nordic nirvana? Gender, citizenship, and social justice in the Nordic welfare states. International Studies, 16(2), 242-278.

Lovén, A. (2000). Kvalet inför valet [The unerving decision]. Studia psychologica et paedagogica - seies altera 152. Malmö: Reprocentralen, Lärarutbildningen.

Lykke, N. (2009). Genusforskning - en guide till feministisk teori, metodologi och skrift [Gender research]. Stockholm: Liber.

Magnusson, C., \& Nermo, M. (2014). Familjeansvar och könslöneskillnader [Family responsibility and gender pay differences]. Lönsamt arbete - familjeansvarets fördelning och konsekvensr [Profitable work - The distribution and consequences of family responsibilities]. SOU 2014:28. Stockholm: Fritzes.

Martinsson, L., Griffin, G., \& Nygren, K. G. (2016). Introduction: Challenging the myth of gender equality in Sweden. In L. Martinsson, G. Griffin, \& K. G. Nygren (Eds.), Challenging the myth of gender equality in Sweden (pp. 1-22). Bristol: Policy Press.

Mathiesen, I. H., Buland, T., \& Bungum, B. (2010). Kjønn i skolens rådgiving - et glemt tema? [Gender in school based guidance - A forgotten topic?]. Trondheim: SINTEF Teknologi og samfunn.

Meld. St. 20. (2012-2013). På rett vei - Kunnskap gir muligheter [On the right track - Knowledge provides opportunities]. White paper, Report to Storting. Ministery of Education, Norway. 
Meld. St nr. 7. (2015-2016). Likestilling i praksis — Like muligheter for kvinner og men [Equality in practice - Equal opportunities for women and men]. White paper, Report to Storting. Ministery of Education, Norway.

Ministry of Social Affairs and Health. (n.d.). Finland is a gender equality pioneer. Retrieved from https://stm.fi/en/finland-is-a-gender-equality-pioneer

Nordic Information on Gender (NIKK). (2018). Comparison important years. Retrieved from http://www.nikk.no/en/facts/comparisons/important-years/

Norges offentlige utredninger (NOU) 2011:18. (2011). Struktur for likestilling [Structure for equality]. Ministry of Children, Equality and Social Inclusion. Norges offentlige utredninger [Norwegian public inqueries].

Norges offentlige utredninger (NOU) 2012:15. (2012). Politikk for likestilling [Equality policy]. Ministry of Children, Equality and Social Inclusion. Norges offentlige utredninger [Norwegian public inqueries].

Norges offentlige utredninger (NOU) 2019:3. (2019). Nye sjanser - bedre laring. Kjønnsforskjeller I skoleprestasjoner og utdanningsløp [New chances - Better learning. Gender differences in school performance and education]. Ministry of Education. Norges offentlige utredninger [Norwegian public inqueries].

Organisation for Economic Co-operation and Developmen (OECD). (2018). Is the last mile the longest? Economic gains from gender equality in Nordic countries. Paris: OECD Publishing. doi:10.1787/9789264300040-en

Öun, I. (2014). The conflict work - Family: Sweden in a comparative perspective. In K. Boye \& M. Nermo (Eds.), Lönsamt arbete - familjeansvarets fördelning och konsekvensr [Profitable workThe distribution and consequences of family responsibilities] (pp. 257-280). SOU 2014:28.

Patton, W., \& McMahon, M. (2014). Career development and systems theory: Connecting theory and practice. Rotterdam, The Netherlands: Sense Publishers.

Pryor, R. G. L., \& Bright, J. E. H. (2011). The chaos theory of careers: A new perspective on working in the 21st century. New York, NY: Routledge.

Reisel, L. (2014). Kjønnsdeling på tvers [Gender segregation across]. In L. Reisel \& M. Teigen (Eds.), Kjønnsdeling og etniske skiller på arbeidsmarkedet [Gender segregation and ethnic divisions in the labor market] (pp. 30-47). Oslo: Gyldendal Akademisk.

Reisel, L., \& Teigen, M. (2014). Det kjønnsdelte arbeidsmarkedet [The gender divide in the labour marked]. In L. Reisel \& M. Teigen (Eds.), Kjønnsdeling og etniske skiller på arbeidsmarkedet [Gender segregation and ethnic divisions in the labour market] (pp. 11-29). Oslo: Gyldendal Akademisk.

Røysum, A. (2016). Arbeidsmoral forkledd som likestilling? [Work ethic disguised as gender equality?] Søkelys på arbeidslivet, 33(1-2), 142-161.

Schulstok, T., \& Svoen, B. (2014). Synlig som et tema, men integrert som en tilncerming. Kjønnslikestilling og flerkulturelle perspektiver i rådgivningsutdanningene (KLF-RU) [Visible as a theme, but integrated as an approach. Gender equality and multicultural perspectives in counseling education]. Høgskolen $\mathrm{i}$ Lillehammer: Arbeidsnotat 215/2014.

Sjöstedt Landén, A., \& Olofsdotter, G. (2016). 'What should we do instead?' Gender-equality projects and feminist critique. In L. Martinsson, G. Griffin, \& K. G. Nygren (Eds.), Challenging the myth of gender equality in Sweden (pp. 163-186). Bristol: Policy Press.

Skolinspektionen Rapport 2013:5. (2013). Studie- och yrkesvägledning i grundskolan. Kvalitetsgranskning Rapport 2013:5. Skolverkets allmänna råd med kommentarer (2013). Arbete med studie- och yrkesvägledning. Stockholm: Fritzes.

Skolverket. (2013). Skolverkets allmänna råd med kommentarer. Arbetet med studie- och ykresvägledning. Stockholm: Fritzes.

SOU 2015:50. (2015). Hela lönen, hela tiden - Utmaningar för ett jämställt arbetsliv [Full pay, full time. Challenges for an equal labour marked]. Stockholm: Fritzes Förlag.

SOU 2015:97. (2015). Välja yrke [Choosing a vocation]. Stockholm: Fritzes Förlag.

Statistisk Sentralbyrå [Statistics Norway]. (2018). Dette er kvinner og menn i Norge [This is women and men in Norway]. Oslo, Norway. Retrieved from https://www.ssb.no/befolkning/artikler-ogpublikasjoner/ attachment/341883 
Teigen, M. (2014). Kjønnsdeling på langs [Horizontal gender division]. In L. Reisel \& M. Teigen (Eds.), Kjønnsdeling og etniske skiller på arbeidsmarkedet [Gender segregation and ethnic divisions in the labor market] (pp. 48-64). Oslo: Gyldendal Akademisk.

Teigen, M. (Ed.). (2015). Gender balance on company boards: A summary from a research project about the impact of the Norwegian gender quota legislation. Report. Institutt for samfunnsforskning.

Teigen, M., \& Skjeie, H. (2017). The Nordic gender equality model. In O. Knutsen (Ed.), The Nordic models in political science: Challenged, but still viable? (pp. 125-147). Bergen: Fagbokforlaget.

Teigen, M., \& Wangnerud, L. (2009). Tracing gender equality cultures: Elite perceptions of gender equality in Norway and Sweden. Politics \& Gender, 5, 21-44.

Tellhed, U., Bäckström, M., \& Björklund, F. (2017). Will I fit in and do well? The importance of social belongingness and self-efficacy for explaining gender differences in interests in STEM and HEED majors. Sex Roles, 77(1), 86-96.

Utdanningsdirektoratet. (2009). Retten til nødvendig rådgivning [The right to necessary guidance]. Endring i forskrift til opplæringsloven kap 22 [Regulations for the education act Chapter 22]. Norway: Utdanningsdirektoratet. Retrieved from https://www.udir.no/regelverkstolkninger/ opplaring/Skoleeiers-ansvar/Udir-2-2009-Retten-til-nodvendig-radgiving/

Wagner, I. (2018). Certified equality: The Icelandic equal pay standard. Report. Institute for Social Research.

Wajcman, J. (1991). Feminism confronts technology. Cambridge: Polity Press.

Wikstrand, F. (2011). Det tekniska spelet. Förhandlingar om arbete, teknik och kön i relation till införande av nya informationssystem [The technical game. Negotiation of work, technology and gender in relations to the introduction of new information systems]. Göteborg: Skrifter från institutionen för arbetsvetenskap vid Göteborgs universitet 10.

Wikstrand, F. (2019). Norm criticism: A method for social justice in career guidance. In T. Hooley, R. Sultana, \& R. Thomsen (Eds.), Career guidance for emancipation - Reclaiming Justice for the multitude (pp. 216-231). New York, NY: Taylor \& Francis/Routledge.

Wikstrand, F., \& Lindberg, M. (2015). Tala om arbetslivet [Talk about working life]. Stockholm: Skolverket.

Zimmerman, F. (2018). Det tillåtande och det begränsande [The allowing and the limiting]. Gothenburg: Axta Universitatis Gothoburgensis. 